Rev. Bras. Saúde Prod. Anim., Salvador, v.16, n.1, p.93-105 jan./mar., 2015 http://www.rbspa.ufba.br

\title{
Blood and bone parameters of cattle fed diets containing different phosphates and phosphorus: fluorine relations
}

\section{Parâmetros sanguíneo e ósseo de bovinos alimentados com dietas contendo diferentes fosfatos e relações fósforo: flúor}

TEIXEIRA, Alexandre de Oliveira ${ }^{1}$; LEONEL, Fernando de Paula ${ }^{1 *}$; KNOOP, Rainer ${ }^{2}$; MOREIRA, Leonardo Marmo ${ }^{1}$; RIBEIRO, Everton Teixeira ${ }^{3}$; OLIVEIRA, Will Pereira $\mathrm{de}^{4}$; CARVALHO, Juliana do Carmo ${ }^{1}$; FERREIRA, Vanusa Patrícia de Araújo ${ }^{1}$; ZERVOUDAKIS, Joanis Tilemahos ${ }^{5}$

\footnotetext{
${ }^{1}$ Universidade Federal de São João del-Rei, Departamento de Zootecnia, São João del-Rei, Minas Gerais, Brasil.

${ }^{2}$ Consultor Técnico, São Paulo, Brasil.

${ }^{3}$ Universidade Federal de Viçosa, Departamento de Zootecnia, Viçosa, Minas Gerais, Brasil.

${ }^{4}$ Instituto Federal Fluminense, Bom Jesus do Itabapoana, Rio de Janeiro, Brasil.

${ }^{5}$ Universidade Federal do Mato Grosso, Faculdade de Agronomia, Medicina Veterinária e Zootecnia, Cuiabá, Mato Grosso, Brasil.

*Endereço para correspondência: alexandre_teixeira@ufsj.edu.br
}

\section{SUMMARY}

Forty-nine male calves were allotted in a randomized design, being that initially were performed seven replicates per treatment. At the end of the experiment were slaughtered four animals per treatment. The treatments were designed as following: CONT: control diet; DC120: Dicalcium Phosphate 120:1 ratio P: F; MDCP60: Monodicalcium Phosphate 60:1 ratio P: F; DC30: Dicalcium Phosphate 30:1 ratio P: F; TSP30: Triple Superphosphate 30:1 ratio P: F; DC10: Dicalcium Phosphate 10:1 ratio P: F; PRC10: phosphate rock concentrate of 10:1 of relation P: F. Alkaline phosphatase (ALP) of animals who consumed PRC10 diet was greater than the ALP of animals that consumed TSP30, DC10 and DC120. This result was obtained with animals with 650 days of confinement. The ALP of the animals that consumed PRC10 was greater at 866 days than in the animals consuming TSP30 and DC120 diets. The ash content was greater in the DC10 diet and the diets CAR10 and DC120 achieved the lowest value. The fluorine content in bone was higher in diet DC10, while the diets DC120, PRC10 and MDCP60 obtained the lower values. The area of Haversian canals and the relation Havers/Osteon area were higher in the diet DC30 and the lowest value was encountered in DC10. The mottled teeth were more intensely observed in the treatments DC10 and PRC10. It was concluded that high fluorine content in the diet increases the deposition of fluorine in bones, which negatively affects in the histological parameters of teeth and bones of beef cattle.

Keywords: alkaline phosphatase, bone strength, calcium, fluorosis, nutrition

\section{RESUMO}

Quarenta e nove novilhos machos foram distribuídos em delineamento casualizado, sendo que inicialmente foram efetuadas sete repetições por tratamento $\mathrm{e}$, ao final do experimento, foram abatidos quatro animais por tratamento. Os tratamentos foram; CONT: Dieta controle; FBC120: Fosfato Bicálcico 120:1 de relação P: F; MBC60: Fosfato monobicálcico 60:1 de relação P:F; FBC30: Fosfato Bicálcico 30:1 de relação P:F; SFT30: Super Fosfato Triplo 30:1 de relação P:F; FBC10: Fosfato Bicálcico 10:1 de relação P:F; CAR10: Concentrado de Rocha 10:1 de relação P:F. A fosfatase alcalina (FA) dos animais aos 650 dias de confinamento, os quais consumiram dieta CAR10, foi maior dos que a FA naqueles que consumiram SFT30 e FBC10 e FBC120. A FA dos animais que consumiram CAR10 foi maior, 
aos 866 dias, do que àquela observada nos tratamentos com SFT30 e FBC120. O teor de cinza foi maior na dieta $\mathrm{FBC} 10$ e as dietas CAR10 e FBC120 representaram o menor valor. O teor de flúor no osso foi maior nos animais da dieta $\mathrm{FBC} 10$ em relação àqueles das dietas CAR10, sendo que as dietas FBC120 e MBC60 obtiveram menores teores. A área dos canais de Havers e a relação Havers/área do Osteon foram maiores na dieta FBC30, sendo que o respectivo menor valor foi FBC10. A presença de dentes mosqueados foi superior nos animais tratados com FBC10 e CAR10. Concluiu-se que o alto teor de flúor na dieta aumenta a deposição de flúor nos ossos, o que afeta negativamente nos parâmetros histológicos de dentes e ossos de bovinos de corte.

Palavras-chave: cálcio, fluorose, fosfatase alcalina, nutrição, resistência óssea

\section{INTRODUCTION}

Usually, the tropical forages are deficient in several mineral salts. Phosphorus deficiency is maybe the most common and it is associated to the most effective economic losses in bovine production (TOKARNIA et al., 2010). Frequently, the phosphorus deficiency is corrected employing conventional sources of this chemical element, which is the case of the dicalcium phosphate (DC). There are other alternative phosphate sources, such as the rock phosphate; triple superphosphate; and the monodicalcium phosphate (MDCP), which should be more studied in order to verify the possibility of employment as substituent to DC. Some of these sources may present less effective phosphorus available to the animal and also provide a high level of fluorine, which can provoke intoxications. In agreement with Marçal et al. (2005), the dental fluorosis could occur before that the production and reproduction can be affected, implying in risk to the mental and public health.
Fluorine (F), in very low quantities, can increase the structural force of bones and teeth. Nevertheless, this element is not considered an essential nutrient in the bovine diet (NRC, 2005). Fluorine is considered toxic for domestic animals due to its accumulation in the bones, which is called fluorosis. Fluorosis provokes bone fractures, lameness, mottling, spot and erosion of the teeth. In fact, these phenomena are typical of chronic intoxications by fluorine, since the acute intoxications cases are very rare, being associated to great ingestions of some compounds, such as fluoridric acid (HF), silicon tetrafluoride $\left(\mathrm{SiF}_{4}\right)$, sodium fluoride $(\mathrm{NaF})$ and sodium tetrafluorosilicate.

Additionally, together with the bone symptoms, histopathological studies have demonstrated the presence of edemas and ulcerations in ruminal and abomasal tissues (LUCIOLI, 2007). Pilati et al. (1996) suggest the use of a diagnosis methodology for phosphorus deficiency, which is based on histopathological and micro-radiographic exams of bovine rib bones aiming the evaluation of the efficacy of the phosphorus supplement in bovine livestock maintained in regions of soils with deficiency of this element.

Thus, this study was performed to evaluate the effect of different phosphorus sources as well as phosphorus:fluorine relations in the diet of bovines of Nellore breed, employing blood, bone and dental analysis.

\section{MATERIAL AND METHODS}

The present study was developed at Araçatuba, São Paulo state, Brazil. This city is located in a region of subtropical climate (Cfa), in agreement with the classification of Köppen, with raining summer, dry winter and annual 
Rev. Bras. Saúde Prod. Anim., Salvador, v.16, n.1, p.93-105 jan./mar., 2015 http://www.rbspa.ufba.br ISSN 15199940

precipitation around $1245 \mathrm{~mm}$ (SigRH/SP, 2006). The annual average temperature oscillates between $15.8^{\circ} \mathrm{C}$ and $31.9^{\circ} \mathrm{C}$ (CIIAGRO, 2006).

In the present study, 49 castrated male steers of Nellore breed were used. These steers were weaned with initial age of 9 months and $230 \mathrm{Kg}$ of live weight (LW). The post weaning calves obtained from a herd of 300 animals, after selection process with employment of a criterion of lower standard deviation of the herd to a variable weight.

The animals were distributed in a randomized way in the treatments, constituting a completely randomized design (CRD), with seven treatments (Table 1) and seven repetitions. The animal represented the experimental unity.

Table 1. Chemical composition and ingestion of the phosphorus sources evaluated

\begin{tabular}{llcccc}
\hline \multirow{2}{*}{ Treatments } & \multirow{2}{*}{ Phosphorus sources } & \multicolumn{3}{c}{ Chemical composition of the } & phosphorus source \\
\cline { 3 - 5 } & & $\mathrm{P}(\%)$ & $\mathrm{Ca}(\%)$ & $\mathrm{F}(\%)$ & Relation P:F \\
\hline CONT & Vegetal & 0 & 0 & 0 & - \\
DC120 & Dicalcium phosphate & 18.1 & 24.0 & 0.15 & 121 \\
MDCP60 & Monodicalcium phosphate & 20.5 & 20.1 & 0.32 & 64 \\
DC30 & Dicalcium phosphate & 18.1 & 24,0 & 0.60 & 30 \\
TSP30 & Triple superphosphate & 19.6 & 16.3 & 0.9 & 22 \\
DC10 & Dicalcium phosphate & 18.1 & 24.0 & 1.4 & 13 \\
PRC10 & Phosphate rock concentrate & 15.6 & 35.9 & 2.0 & 8 \\
\hline
\end{tabular}

CONT $=$ Control diet DC120 $=$ Dicalcium phosphate 120:1 of relation P:F; MDCP60 $=$ Monodicalcium Phosphate 60:1 of relation P:F; DC30 = Dicalcium Phosphate 30:1 of relation P:F; TSP30 = Triple Superphosphate 30:1 of relation P:F; DC10 = Dicalcium Phosphate 10:1 of relation P:F; PRC10 $=$ Phosphate rock concentrate 10:1 of relation P:F

The animals were disposed in cattle bays, which contained feeders and water drinkers. The animals received complete mineral mixture, except phosphorus, in an isolated feeder, which has been specifically prepared to this supplementation available ad libitum.

The phosphorus sources used in this study were commercial products available in the market $\mathrm{e}$ allowed by Brazilian legislation, being fed to the animals is sufficient to allow the daily intake of 4.5 grams of phosphorus per animal per day amount.

In order to obtain a total and homogeneous ingestion of the phosphorus sources furnished to the animals, triturated corn was mixed in the proportion of $0.250 \mathrm{Kg}$.animal.day ${ }^{-1}$.
The complete diet (roughage and concentrate) was based in the supply of roughage, which was represented by hydrolyzed sugarcane bagasse (Table $2)$. The roughage was supplied to the individuals in appropriate quantity, which has been adjusted by evaluation of the diary rests in the feeders. The ration was furnished in a proportion of $1 \%$ of the body weight (BW) of the animal.

The complementary ration (Table 2) was elaborated to furnish the lower phosphorus addition that is possible to a weight gain of, approximately $0.6 \mathrm{~kg}$ day $^{-1}$ by animal, in agreement with recommendations of NRC (1996). The phosphorus required to this gain was given from the test sources; indeed, the phosphorus was furnished in its 
Rev. Bras. Saúde Prod. Anim., Salvador, v.16, n.1, p.93-105 jan./mar., 2015 http://www.rbspa.ufba.br ISSN 15199940

isolated form, with exception of the control treatment, which did not receive supplementary phosphorus.

The complete diet, with exception of the experimental treatments, was supplied to the animals at 8:00 a.m. and at 4:00 p.m., in equal quantities. The test sources were supplied only in the morning treatment, in agreement with previous description. The treatments were placed together with the feed (at the top of the feed layer) in order to allow these compounds to be ingested by the animals in order to ensure complete intake of the phosphorus source.

Table 2. Centesimal and nutritional composition of the basal ration

\begin{tabular}{lccccc}
\hline Ingredients & \% in the diet & $\mathrm{PB}(\%)$ & $\mathrm{P}(\%)$ & $\mathrm{Ca}(\%)$ & $\mathrm{F}(\%)$ \\
\hline Soybean Hulls & 91.104 & 30.66 & 0.14 & 0.49 & 0.01 \\
Hydrogenated Fat & 4.442 & 0.82 & 0.06 & 9.00 & 0.01 \\
Corn Gluten Meal & 1.117 & 65.29 & 0.44 & 0.12 & 0.06 \\
Urea & 3.337 & 281.00 & 0.00 & 0.00 & 0.00 \\
Calculated total & 100.000 & 38.30 & 0.14 & 0.85 & 0.01 \\
Hydrolyzed sugarcane bagasse & ad libitum & 1.43 & 0.04 & 0.118 & 0.006 \\
\hline
\end{tabular}

The experimental period lasted 927 days, being that the 81 first days were employed to the adaptation of the animals to the diet and the installations. At the beginning of the experiment and, subsequently, to each interval of six months, during the experimental period, in days that correspond to the management of the animal weight determination, it was made collection of blood samples, in all animals of the group to the determination of the alkaline phosphatase (ALP).

The animals were immobilized in a cattle chute, and the blood was collected via jugular vein with individual meddle and vacutainer. The samples were centrifuged using $3.000 \mathrm{rpm}$ during 15 minutes.

The determination of ALP was performed by kinetic method with application of sodium para-nitrophenyl phosphate (PNPP), with reaction temperature of $37^{\circ} \mathrm{C}$ and utilizing the commercial kit and semi-automatic biochemical analyzer.

At the end of the experiment, 28 animals (four animals for each treatment) were slaughtered with average weight of $637 \pm 61 \mathrm{Kg}$. The phalange (phalanx) of the right anterior member of the animals were collected and disposed in a recipient with boiling temperature, to soften the skin and the meat. Subsequently, they were stripped off and the phalange was defatted in Soxhlet extractor, disposed in a ventilated greenhouse at $65^{\circ} \mathrm{C}$ for $72 \mathrm{~h}$ and crushed in a ball mill. The definitive drying process was taken in greenhouse at $105^{\circ} \mathrm{C}$ for 24 hours. The ash quantities were determined in muffle at $600^{\circ} \mathrm{C}$. One gram $(1 \mathrm{~g})$ of dry and ground sample was disposed in digestion tubes, adding $25 \mathrm{~mL}$ of nitro-perchloric solution $(1: 1)$ at $160^{\circ} \mathrm{C}$ until the solution becomes colorless. The determinations of mineral levels in the bones were obtained by spectrophotometry of atomic absorption, except phosphorus, which was quantified by spectroscopy of electronic absorption in the ultraviolet-visible region and fluorine, which was analyzed by Potentiometry (CBAA, 2009). 
The metacarpal bone (right anterior member) was maintained in ventilated greenhouse at $65^{\circ} \mathrm{C}$ for 72 hours. Subsequently, the respective bone was submitted to tests of resistance to fracture or shearing, employing a specific pressing apparatus (California Index).

A fragment of the tenth rib, with approximately $1 \mathrm{~cm}$ of length was collected from each animal around $20 \mathrm{~cm}$ below the costovertebral joint. This procedure was made for posterior histological analysis. The rib fragments were washed in physiological solution, fixed in formaldehyde (10\%), dehydrated in ethylic alcohol, treated in xylol and included in paraffin. Cuts with seven (7) $\mu \mathrm{m}$ of thickness were made with the microtome, being these cuts stained with hematoxylin and eosin (HE). Fifteen (15) observations were made in distinct sites of the cortical bone surface, aiming to determine the thickness of the compact layer, which includes the periosteal surface until the trabecular bone (JUNQUEIRA, 2004). Furthermore, in the compact layer of the rib bone, the areas of 15 osteons and their respective areas of aperture of the canals of Havers was analyzed. The percentage of canals of Havers area/Osteon area were determined (Figure 1).

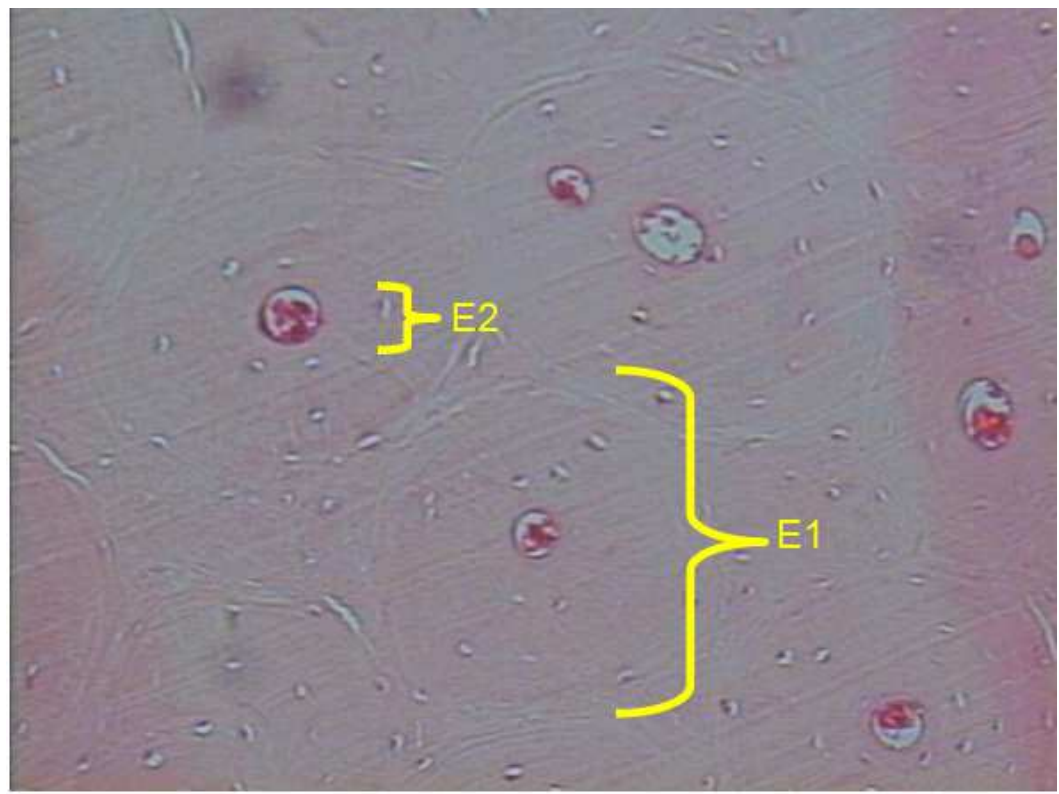

Figure 1. Compact layer of bovine rib bones (transversal cut). Detail: (E1) Osteon; and (E2) Canals of Havers (Haversian Canals). Obj.10x. Increase: 40x, Hematoxylin and Eosin (HE)

Dental fluorosis in bovines was diagnosed by exams of the permanent incisive teeth, since the deciduous dentition did not exhibit alterations as function of the excess of fluorine in the diet. To classify the different levels of dental alterations generated by fluorine, it was employed the system of points (score) proposed by NRC (1974).

The variables were evaluated employing the procedures of variance analysis contained in the system STATISTICA 6.0 , being that the medium value of the treatments with supplementary sources 
Rev. Bras. Saúde Prod. Anim., Salvador, v.16, n.1, p.93-105 jan./mar., 2015 http://www.rbspa.ufba.br ISSN 15199940

were compared by SNK test $(\mathrm{P}<0.05)$. Furthermore, the media of the treatments containing supplementary phosphorus sources were compared with the CONT by Dunnett test $(\mathrm{P}<0.05)$.

\section{RESULTS AND DISCUSSION}

The alkaline phosphatase (ALP) in the animals that ingested the PRC10 diet was higher than in the individuals that received the TSP30 and DC10 diets in 650 days of confinement (Table 3 ). The MDCP60 and DC30 diets generated intermediary values and the DC120 diet propitiated the lower value. The ALP with 866 days of confinement was more intense in the animals that ingested PRC10 diet in comparison with the individuals that ingested TSP30 and DC120 diets, being that the MDCP60, DC30 and DC10 diets presented intermediary levels. With 399 days of confinement, animals that ingested the
CONT diet obtained the higher level of PA, when compared with the animals that received the MDCP60 diet. With 650 and 866 days of confinement, animals that ingested the CONT diet obtained a higher PA value in relation to the animals associated to the other diets evaluated in the present study.

The values of the alkaline phosphatase (ALP) enzyme decreased in the beginning of the experiment until the 866 days of age, being that Moraes (2011) assigned the high values of ALP in younger animals to the great quantity of bone ALP isoenzymes, which are released in animals in growth and that can be three times higher than the adult animals. The values found in the present work to ALP are superior ones to the higher value related by Kaneko et al. (2008), (of $0-488$ ), in the start of the experiment, being that these limits reached in the animals after 399 days, except to the animals without consumption of supplementary source of phosphorus.

Table 3. Alkaline phosphatase (ALP) in the blood of bovines feed with different phosphorus sources and fluorine levels as function of the number of confinement days

\begin{tabular}{|c|c|c|c|c|c|c|c|c|}
\hline \multirow{2}{*}{$\begin{array}{l}\text { Alkaline Phosphatase } \\
\text { (ALP) parameters }\end{array}$} & \multicolumn{7}{|c|}{ Treatments $^{1}$} & \multirow{2}{*}{$\begin{array}{l}\mathrm{CV} \\
(\%)\end{array}$} \\
\hline & CONT & DC120 & MDCP60 & DC30 & TSP30 & DC10 & PRC10 & \\
\hline ALP $(\mathrm{U} / \mathrm{L})$ in the begining & 1249 & 1305 & 1263 & 1279 & 1209 & 1362 & 1343 & 11.32 \\
\hline ALP (U/L) 148 days & 776 & 596 & $524^{*}$ & 669 & 664 & 610 & 670 & 20.87 \\
\hline ALP (U/L) 399 days & 748 & $391^{*}$ & $439^{*}$ & $375^{*}$ & $470^{*}$ & $357^{*}$ & $441^{*}$ & 32.36 \\
\hline $\operatorname{ALP}(\mathrm{U} / \mathrm{L}) 650$ days & 714 & $244^{* \mathrm{c}}$ & $353^{* b}$ & $349^{* \mathrm{~b}}$ & $421^{* a b}$ & $369^{* a b}$ & $440^{*_{a}}$ & 16.46 \\
\hline ALP (U/L) 866 days & 714 & $203^{* b}$ & $219^{* a b}$ & $237^{* \mathrm{ab}}$ & $207^{* \mathrm{~b}}$ & $260^{* a b}$ & $303^{*_{a}}$ & 26.25 \\
\hline
\end{tabular}

Nicodemo (2000) also founded an accentuated increase of PA in bovines that received $5 \mathrm{~g}$ of diary phosphorus in the diet (without supplementation), in comparison with the bovines submitted to treatments in which the animals received a diet with phosphorus supplies, which propitiated a diary 
Rev. Bras. Saúde Prod. Anim., Salvador, v.16, n.1, p.93-105 jan./mar., 2015 http://www.rbspa.ufba.br ISSN 15199940

ingestion of 11 and 15 grams per animal.

It would be expected to find lower concentrations of ALPs associated to more soluble sources, due to the higher phosphorus availability for the animal. However, in agreement with the results of the present work, the phosphorus solubility in the source has no effect in the laboratory analysis. It is possible that the higher availability might be counterbalanced by a more effective elimination by kidneys, since the hydro solubility can influence decisively in the relative increase of the excretion through the urine.

In a previous study, it was observed that ALP of swine was not significantly influenced by the substitution of dicalcium phosphate (DC) by monodicalcium phosphate (MDCP) in the diet, in the growth and finishing phases (TEIXEIRA et al., 2005). However, in the present work, it was observed the occurrence of an increase of ALP with the substitution of dicalcium phosphate (DC) by phosphate rock concentrate (PRC).

Therefore, the present findings are in agreement with Teixeira et al (2013a). In fact, in this article, higher values of ALP were encountered in pigs in the growth phase that ingested triple superphosphate
(TSP), single superphosphate (SS), phosphate rock concentrate (PRC) and mixtured sources (MIX) when compared with the animals that received dicalcium phosphate (DC) and Monodicalcium phosphate (MDCP) (TEIXEIRA et al., 2013a).

Analyzing the data, it is observed that the bone turnover generates affects the blood, changing the levels of enzymes, minerals salts and other substances involved in the apposition and reabsorption of bones. However, this analysis represents great economic advantage in relation to other methods, since does not employ the animal slaughter. Moreover, Duarte et al. (2011) observed that the alkaline phosphatase (ALP) in the serum is less significant in the diagnosis of phosphorus deficiency. The bone deformation (Table 4) was higher $(\mathrm{P}<0.05)$ in the animals that ingested the DC10 and TSP30 diets, being that the MDCP60 and DC30 diets obtained intermediary values and the PRC10 and DC120 diets presented the lower values, between the treatments evaluated in this work. The CONT diet propitiated lower resistance of the bones in comparison with the treatments containing supplementary source of phosphorus.

Table 4. Resistance and deformation until the bone fracture of bovines feed with different phosphorus sources and fluorine levels

\begin{tabular}{lcccccccc}
\hline \multirow{2}{*}{ Parameters } & \multicolumn{6}{c}{ Treatments $^{1}$} & \multirow{2}{*}{ CV (\%) } \\
\cline { 2 - 6 } & CONT & DC120 & MDCP60 & DC30 & TSP30 & DC10 & PRC10 & \\
\hline $\begin{array}{l}\text { Resistance (kgf) } \\
\begin{array}{l}\text { Deformation until the } \\
\text { fracture (mm) }\end{array}\end{array}$ & 1236 & $1863^{* *}$ & $2087^{*}$ & $2211^{*}$ & $1809^{* *}$ & $2073^{*}$ & $1786^{* *}$ & 14.33 \\
\hline
\end{tabular}

${ }^{1}(\mathrm{P}<0.05)$ Medium values followed of distinct letters in the respective line are mutually different by the Student-Newman-Keuls test.

*Different medium values $(>$ ou $<$ ) in relation to the CONT (negative control) diet, by Dunnett test at $1 \%$.

**Different medium values (> ou $<$ ) in relation to the CONT (negative control) diet, by Dunnett test at $5 \%$.

$\mathrm{CV}=$ coefficient of variation. 
It is important to notice that fluorine is considered an element with high toxicity to domestic animals, which is generated, basically, by the possibility of accumulation in the bones. Therefore, in situations of continuous ingestion, the cumulative character of the fluorine in the bones can provoke fractures almost spontaneously, i.e., fractures that was not originated by mechanical chocks of great impact (trauma). Furthermore, excessive accumulation of fluorine in the bones provokes also lameness, mottling, spot and erosions in the teeth (NRC, 2005).

The supplementary sources of phosphorus were not significant influences $\quad(\mathrm{P}>0.05)$ upon the phosphorus and calcium levels in the bones of the animals (Table 5). However, they influenced $(\mathrm{P}<0.05)$ the quantities of ash and fluorine of the bones. Animals that consumed the CONT diet demonstrated lower $(\mathrm{P}<0.05)$ level of ash than the ones that ingested the MDCP60, DC30 and DC10 diets. The value of ash was higher $(\mathrm{P}<0.05)$ in the animals that ingested the DC10 diets, being that the MDCP60, DC30 and TSP30 diets obtained intermediary values, while the PRC10 and DC120 diets demonstrated the lower values of this analysis. The quantity of fluorine was higher $(\mathrm{P}<0.05)$ in the animals that ingested the DC10 diet in relation to animals that consumed PRC10; being that this diet presented superior level of fluorine in relation to the animals that consumed DC30 and MDCP30. The DC120 and MDCP60 diets obtained the lower indexes of fluorine in the bones.

Table 5. Quantities of minerals in the bovine bones feed with different phosphorus sources and fluorine levels

\begin{tabular}{lcccccccc}
\hline \multirow{2}{*}{ Parameters $^{1}$} & \multicolumn{7}{c}{ Treatments $^{2}$} & CV \\
& CONT & DC120 & MDCP60 & DC30 & TSP30 & DC10 & PRC10 & $(\%)$ \\
\hline Dry matter (\%) & 81.68 & 82.60 & 85.23 & 85.4 & 85.25 & 84.62 & 82.25 & \\
Ash (\%) & 46.80 & $48.54^{\mathrm{b}}$ & $52.17^{* \mathrm{ab}}$ & $52.10^{* \mathrm{ab}}$ & $50.42^{\mathrm{ab}}$ & $55.23^{* \mathrm{a}}$ & $48.73^{\mathrm{b}}$ & 4.55 \\
Total P (\%) & 8.26 & 9.08 & 8.98 & $9.36^{*}$ & 8.94 & $9.52^{*}$ & 8.60 & 4.86 \\
Calcium (\%) & 18.96 & 19.23 & 19.46 & 19.85 & 19.13 & 20.35 & 18.58 & 5.61 \\
Fluorine (mg/Kg) & 836.97 & $1324.11^{\mathrm{d}}$ & $1623.30^{\mathrm{d}}$ & $2990.43^{* \mathrm{c}}$ & $3704.00^{*_{\mathrm{c}}}$ & $6904.29^{* \mathrm{a}}$ & $5498.59^{* \mathrm{~b}}$ & 15.23 \\
\hline
\end{tabular}

${ }^{\mathrm{T}}$ Values presented concerning to Dry Matter $(\mathrm{DM}) ;{ }^{2}(\mathrm{P}<0.05)$ Medium values followed of distinct letters in the respective line are mutually different by Student-Newman-Keuls test.

*Different medium values ( $>$ ou $<$ ) in relation to the CONT diet (negative control), by Dunnett test with $1 \%$.

**Different medium values (> ou <) in relation to the CONT diet (negative control), by Dunnett test with 5\%.

$\mathrm{CV}=$ coefficient of variation.

Godoy et al. (2000a) evaluated the natural phosphates, the triple superphosphate and the monodicalcium phosphate (MDCP) and did not observe significant difference in the density and in the content of ash of the bones. The monodicalcium phosphates (MDCP) and triple superphosphate (TSP) were the most biologically available sources and, in the case of fluorine, the rock phosphate and the triple superphosphate provoked higher retention (GODOY, 2000b). These results are in agreement with the NRC (2005), in which the fluorine absorption varies with the physical form and/or chemical constitution of the respective source. Indeed, the sodium fluoride is fast and efficiently absorbed (above of 90\%), while around $50 \%$ of the fluorine present in the rock phosphates is absorbed. These data constitute extremely relevant information, since that the fluorine 
percentage in the bones depends on the fluorine quantity present in the diet, i.e., there is a direct relation between the fluorine quantity present in the diet and the fluorine retention in the bone by the animal that receives the respective diet. Humberto (2007), evaluating phosphorus and fluorine sources to sheep, identified that the fluorine deposition in ribs was ten times lower in the animals fed with dicalcium phosphate in relation to the ones fed with rock phosphate and sodium fluoride, being that the deposition of fluorine was higher when the fluorine was originated of the sodium fluoride.

In laboratory animals treated with sodium fluoride, in a chronic way, it was related subnormal growth and significant decrease in the body weight when compared with the control animals (PUSHPALATHA et al., 2005). Filappi et al. (2008) working with ovines treated with sodium fluoride, concluded that the chronic administration of fluorine induced to the accumulation of this element in the bones, even with high calcium level in the alimentation. This accumulation, a priori, is not nocive to the animals. Casartelli et al. (2008), employing relations fluorine:phosphorus $1: 40,1: 60,1: 80$ and 1:100 in the diet of chicken, verified that the fluorine deposition in bones is proportional to the concentration of this element in the diet. However, the elevation of the fluorine levels in the diet does not influence its deposition in the muscles and, therefore, are not associated to significant risks to the human health. The area of aperture of the canals of Havers and the relationship between the canals aperture and the Osteon area (Table 6) was higher $(\mathrm{P}<0.05)$ in the bones of the animals that ingested DC30 diet, being similar $(P>0.05)$ to that of the animals associated to the DC120, MDCP60, TSP30 and PRC10 diets. It is relevant to emphasize that the lower value $(\mathrm{P}<0.05)$ was observed to animals that received the DC10 diet. The CONT diet presented lower $(\mathrm{P}<0.05)$ thickness of the compact layer of the bones, when compared with other treatments containing supplementation with phosphorus sources, with exception of the treatment with PRC10. The bones of the animals that consumed the CONT diet presented lower $(\mathrm{P}<0.05)$ relation Havers area/Osteon area in comparison with that animals that ingested DC30. Pilati et al. (1997) do not observed histological abnormalities in the bovine bones, suggesting the utilization of rock phosphate to bovine nutrition.

Table 6. Histology of the bovine bone feed with different phosphorus sources and fluorine levels

\begin{tabular}{lcccccccc}
\hline \multirow{2}{*}{ Parameters } & \multicolumn{9}{c}{ Treatments $^{1}$} & CV \\
\cline { 2 - 7 } & CONT & DC120 & MDCP60 & DC30 & TSP30 & DC10 & PRC10 & $(\%)$ \\
\hline $\begin{array}{l}\text { Thickness of compact layer } \\
(\mu \mathrm{m})\end{array}$ & 673 & $1129^{*}$ & $1086^{*}$ & $1070^{*}$ & $957^{* *}$ & $1070^{*}$ & 875 & 13.5 \\
Osteon area $\left(\mu \mathrm{m}^{2}\right)$ & 41389 & 47849 & 41938 & 38632 & 40924 & 40197 & 43046 & 21.1 \\
Area of canal of Havers $\left(\mu \mathrm{m}^{2}\right)$ & 1006 & $1345^{\mathrm{ab}}$ & $1368^{\mathrm{ab}}$ & $1407^{\mathrm{a}}$ & $1219^{\mathrm{ab}}$ & $902^{\mathrm{b}}$ & $1173^{\mathrm{ab}}$ & 18.5 \\
Havers area/Osteon area $(\%)$ & 2.43 & $2.81^{\mathrm{ab}}$ & $3.26^{\mathrm{ab}}$ & $3.64^{* \mathrm{a}}$ & $3.98^{* \mathrm{ab}}$ & $2.24^{\mathrm{b}}$ & $2.72^{\mathrm{ab}}$ & 16.7 \\
\hline
\end{tabular}

${ }^{1}(\mathrm{P}<0.05)$ Medium values followed of distinct letters in the respective line are mutually different by Student-Newman-Keuls test.

*Different medium values ( $>$ ou $<$ ) in relation to the CONT diet (negative control), by Dunnett test with $1 \%$.

**Different medium values (> ou <) in relation to the CONT diet (negative control), by Dunnett test with $5 \%$.

$\mathrm{CV}=$ coefficient of variation. 
Rev. Bras. Saúde Prod. Anim., Salvador, v.16, n.1, p.93-105 jan./mar., 2015 http://www.rbspa.ufba.br ISSN 15199940

The percentage of mottled teeth was superior $(\mathrm{P}<0,05)$ in the animals that consumed DC10 and PRC10 (Table 7). Typically, approximately $99 \%$ of the total fluorine of the body is associated to the calcium of the bones and teeth, which characterizes the called fluorosis. This accumulation is reasonable chemically, since the calcium is found in the divalent form $\left(\mathrm{Ca}^{2+}\right)$, which constitutes a significantly "hard" Lewis acid (that is, with high charge/radium relation), in agreement with the Pearson acid-base concept. Therefore, considering that the fluoride anion $\left(\mathrm{F}^{-}\right)$ is a Lewis base that is considered "hard" by Pearson concept, it is possible to infer that the calciumfluorine $\left(\mathrm{Ca}^{2+}-\mathrm{F}^{-}\right)$interaction, which is a interaction between a "hard" acid and a "hard" base, which represents a predominantly ionic ligation of high chemical stability, favoring, for consequence, the fluoride anions accumulation in the biological tissue that presents great quantity of divalent cations of calcium, which is the case of the bone tissue.

Table 7. Score and classification of the degree of dental fluorosis in bovines feed with different phosphorus sources and fluorine levels

\begin{tabular}{lccccccc}
\hline \multirow{2}{*}{ Parameters } & \multicolumn{7}{c}{ Treatments } \\
\cline { 2 - 8 } & CONT & DC120 & MDCP60 & DC30 & TSP30 & DC10 & PRC10 \\
\hline Mottled teeth (\%) & 12.8 & $7.8^{\mathrm{b}}$ & $6.3^{\mathrm{b}}$ & $9.9^{\mathrm{b}}$ & $10.2^{\mathrm{b}}$ & $29.5^{* *_{\mathrm{a}}}$ & $24.7^{* * \mathrm{a}}$ \\
Worn teeth (\%) & 20.8 & 23.4 & 35.2 & 29.8 & 20.9 & 29.1 & 23.9 \\
Dental erosion (\%) & 7.3 & $18.8^{\mathrm{ab}}$ & $20.3^{\mathrm{ab}}$ & $29.0^{* \mathrm{a}}$ & $17.1^{\mathrm{ab}}$ & $27.3^{*^{* a}}$ & 15.5 \\
Crooked teeth (\%) & 23.4 & 29.7 & 29.7 & 35.6 & 21.9 & 37.5 & 27.2 \\
Score & 2.6 & 3.1 & 3.3 & 3.3 & 2.9 & 3.8 & 2.9 \\
\hline
\end{tabular}

${ }^{1}(\mathrm{P}<0.05)$ Medium values followed of distinct letters in the respective line are mutually different by Student-Newman-Keuls test.

*Different medium values ( $>$ ou $<$ ) in relation to the CONT diet (negative control), by Dunnett test with $1 \%$.

**Different medium values ( $>$ ou $<$ ) in relation to the CONT diet (negative control), by Dunnett test with $5 \%$.

$\mathrm{CV}=$ coefficient of variation.

The toxic effect of fluorine is mainly Characterized by changes in bone and tooth, causing deformations that occur when fluoride reaches odontoblasts and osteoblasts, depending on their role as an enzyme inhibitor (HAYS \& SWENSON, 1988). The results obtained in the present work demonstrated that the fluorine element, mainly obtained of sources with higher biological availability, such as sodium fluoride (NRC, 2005), affects the tooth structure, increasing the bone erosion. These effects can also be observed in the rock phosphates (PRC10), which values of fluorine is also considered significantly elevated.
The fixation sites of several chemical elements in the different biological tissues constitutes a relevant evaluation in order to determine the direct effect of the nutritional strategies upon the healthy and production of the animals as well as the nutritional content of each biological tissue, when employed in the human nutrition (TEIXEIRA, et al., 2013b). Indeed, nutritional strategies aiming a more effective absorption have been evaluated regarding the process of ruminant digestion, aiming to obtain a higher understanding of the chemical interactions between nutrients in the digestive system as well as an 
optimization of the animal nutrition (MOREIRA et al., 2013).

The samples evaluated in the present work involve a significant number of individuals and a representative time interval (above 600 days), allow to infer about the consequences of the chronic use of nutritional sources with high level of fluorine. It is important to note that the dental lesions are very representative symptoms, with very intense deformations, which, certainly, must decrease the capability of mastication (chewing) of the bovines and, for consequence, decrease its weight gain in determined time interval, increasing the costs associated to the development of the respective animal and its total productivity.

The high fluorine content in the diet increases the deposition of fluorine in bones, which negatively affects in the histological parameters of teeth and bones of beef cattle.

\section{REFERENCES}

CASARTELLI, E.M.; JUNQUEIRA, O.M.; ARAÚJO, L.F.; ARAÚJO, C.S.S.; SAVIETTO, D.; TRINDADE NETO, M.A. Fosfatos com diferentes relações flúor: fósforo na alimentação de frangos de corte. Revista Brasileira de Zootecnia [online], v.37, n.5, p.856860, 2008.

\section{CIIAGRO. Quadro de temperatura} média mensal. Disponível em: $<$ http://ciiagro.iac.sp.gov.br/ciiagroonli ne/Quadros/QTmedPeriodo.asp> Acesso em: 29 dez. 2013.

\section{COMPÊNDIO BRASILEIRO DE} ALIMENTAÇÃO ANIMAL - CBAA. Guia de métodos analíticos. Sindirações, 2009. 217p.
DUARTE, A.L.L.; PIRES, M.L.S.; BARBOSA, R.R.; DIAS, R.V.C.; SOTO-BLANCO, B. Avaliação da deficiência de Fósforo em Ruminantes por meio de Bioquímica Sérica. Acta Veterinaria Brasilica, v.5, n.4, p.380384, 2011.

FILAPPI, A.R.; PRESTES, D.S.; ANTES, F.G.; FLORES, E.L.M.; DRESSLER, V.L.; FLORES, E.M.M.; CECIM, M. Metabolismo e distribuição do flúor em ovinos jovens tratados cronicamente com fluoreto de sódio.

Pesquisa Veterinária Brasileira [online], v.28, n.2, p.124-128, 2008.

GODOY, S.; CHICCO, C.F.; OBISPO, N.E. Fuentes de fósforo para la alimentación de bovinos: densidad del tejido óseo. Zootecnia Tropical, v.18, n.1, p.29-44, 2000a.

GODOY, S.; CHICCO, C.F.; REQUENA, F.; OBISPO, N.E. Fuentes de fósforo para la alimentación de bovinos: reteción de fósforo y flúor.

Zootecnia Tropical, v.18, n.1, p.45-58, 2000b.

HAYS, V.W.; SWENSON, M.J. Minerais. In: DUKES, H.H.; SWENSON, M.J. (Eds.). Dukes: fisiologia dos animais domésticos. 10.ed. Rio de Janeiro: Guanabara, 1988. p.397-411.

\section{HUMBERTO, H.J.C. Efeitos da ingestão de flúor provenientes do fosfato de rocha e fluoreto de sódio na fluorose dental de ovinos. 2007. 63p. Dissertação (Mestrado) - Universidade de São Paulo, Pirassununga.}

JUNQUEIRA, L.C. Histologia Básica. 10.ed. Rio de Janeiro: Guanabara Koogan, 2004. 
Rev. Bras. Saúde Prod. Anim., Salvador, v.16, n.1, p.93-105 jan./mar., 2015 http://www.rbspa.ufba.br ISSN 15199940

KANEKO, J.J.; HARVEY, J.W.; BRUSS, M.L. Clinical biochemistry of domestic animals. 6.ed. San Diego: Academic Press, 2008. 928p.

LUCIOLI, J.; FURLAN, F.H.; MEZAROBA, S.; RAYMUNDO, D.L.; BECHTOLD, S.L.; TRAVERSO, S.; GAVA, A. Intoxicação aguda por fluorsilicato de sódio em bovinos do estado de Santa Catarina. Pesquisa Veterinária Brasileira, v.27, p.49-52, 2007.

MARÇAL, W.S.; OLIVEIRA JUNIOR, B.C. de; ORTUNHO, V.V. Teores de fósforo e flúor em suplementos minerais para bovinos comercializados no estado do Paraná. Acta Scientiae

Veterinariae, v.33, n.3, p.315-319, 2005.

MOREIRA, L.M.; LEONEL, F.P.; VEIRA, R.A.M.; PEREIRA, J.C. A new approach about the digestion of fibers by ruminants. Revista Brasileira de Saúde e Produção Animal [online], v.14, n.2, p.382-395, 2013.

NATIONAL RESEARCH COUNCIL NRC. Effects of fluorides in animals. Washington: National Academy Press, 1974. 70p.

NATIONAL RESEARCH COUNCIL NRC. Nutrient requeriments of beef cattle. 6th ed. Washington: National Academy Press, 1996.157p.

NATIONAL RESEARCH COUNCIL NRC. Mineral tolerance of animals. 2th ed. Washington: National Academy of Sciences, 2005. 510p.

NICODEMO, M.L.F.; MORAIS, S.S.; ROSA, I.V.; MACEDO, M.C.M.; THIAGO, L.R.L.S.; ANJOS, C.R. Uso de parâmetros ósseos, plasmáticos e fecais na determinação da deficiência de fósforo em bovinos. Revista Brasileira de Zootecnia, v.29, n.3, p.840-847, 2000 .

PILATI, C.; DUTRA I.S.; BEHRENS, K.; DÖBEREINER, J.; DÄMMRICH, K. Diagnóstico da deficiência de fósforo em bovinos pelos exames histológicos e microrradiográficos de costelas.

Pesquisa Veterinária Brasileira, v.16, n.1, p.27-33, 1996.

PILATI, C.; ROSA; I.V.; DAYRELL, M.S.; DÖBEREINER, J.;

DÄMMRICH, K. Estudos histológicomorfométricos e microrradiográficos de costelas de bovinos suplementados com fosfato de rocha. Pesquisa Veterinária Brasileira, v.17, n.3/4, p.96-104, 1997.

PUSHPALATHA, T.; SRINIVAS, M.; REDDY, P.S. Exposure to high fluoride concentration in drinking water will affect spermatogenesis and steroidogenesis in male albino rats. Biometals, v.18, p.207-212, 2005.

SISTEMA DE INFORMAÇÕES PARA O GERENCIAMENTO DE RECURSOS HIIDRICOS DO ESTADO DE SÃO PAULO - SigRH/SP. Banco de dados pluviométricos do estado de São Paulo. Disponível em: $<$ http://www.sigrh.sp.gov.br/cgibin/bdhm.exe/plu>. Acesso em: 9 jan. 2013.

TEIXEIRA, A.O.; LOPES, D.C.; GOMES, P.C.; LOPES, J.B.; COSTA, L.F.; FERREIRA, V.P.A.; PENA, S.M.; MOREIRA, J.A. Níveis de substituição do fosfato bicálcico pelo monobicálcico em dietas para suínos nas fases de crescimento e terminação. Revista Brasileira de Zootecnia, v.34, p.142150, 2005. 
TEIXEIRA, A. O.; NOGUEIRA, E. T.;

CORASSA, A.; FERREIRA, V.P.A.;

ROCHA JUNIOR, C.M.; LOPES, J.B.;

MOREIRA, L.M. Evaluation of

phosphorus sources on performance, organ weight and blood parameters of pigs. Revista Brasileira de Saúde e Produção Animal [online], v.14, n.4, p.808-819, 2013a.

TEIXEIRA, A.O.; LEONEL, F.L.;

KNOOP, R.; FERREIRA, V.P.A.;

RIBEIRO, E.T.; MOREIRA, L.M.;

PEREIRA, J.C. Mineral deposition in tissues of cattle fed with different phosphates and relationships phosphorus: fluorine. Revista Brasileira de Saúde e Produção

Animal [online], v. 14, n.4, p.831-847, 2013b.

TOKARNIA, C.H.; PEIXOTO, P.V.; BARBOSA, J.D.; BRITO, M.F.; DÖBEREINER J. Deficiências Minerais em Animais de Produção.

Rio de Janeiro: Helianthus, 2010.191p.

Data de recebimento: $17 / 03 / 2014$

Data de aprovação: 23/02/2015 